\title{
RECENZJE
}

Klio. Czasopismo poświęcone dziejom Polski i powszechnym PL ISSN 1643-8191, t. 57 (1)/2021, s. 207-215

\section{Na marginesie książki Państwo Islamskie (ISIS). Historia powstania i taktyka działania, pod red. Krzysztofa Danielewicza, Oświęcim 2019}

\author{
(c) $(1) \Theta$ \\ http://dx.doi.org/10.12775/KLIO.2021.009
}

Dublikacja Państwo Islamskie (ISIS). Historia powstania i taktyka dziatania 1 jest pracą zbiorową pod redakcją Krzysztofa Danielewicza, która ukazała się w Oświęcimiu w 2019 r. nakładem wydawnictwa NapoleonV. Trudno było zakładać biegłą znajomość arabskiego wśród autorów książki, niemniej jednak powinni oni orientować się w nim na tyle, by móc korzystać z oryginalnych źródeł. Tymczasem lektura pracy niestety przyniosła rozczarowanie.

Jak wspomniano, redaktorem książki, a także autorem wstępu i pierwszego rozdziału - Historia powstania oraz ewolucja dziatalności Państwa Islamskiego (Islamic State - IS), jest Krzysztof Danielewicz¹. Kolejną część

1 Według biogramu umieszczonego na stronie jego firmy: „dr Krzysztof DANIELEWICZ, płk rez. Ekspert ds. bezpieczeństwa międzynarodowego, specjalizujący się w Afryce i Azji. Autor prelekcji, procedur i szkoleń z zakresu postępowania w przypadku ataku terrorystycznego. [...] Autor opracowań: Lwowska Ekspozytura Wywiadu. Dziatalność Ekspozytury nr 5 SG we Lwowie w latach 1921-1939, Torun 2011 i 2017, Terroryzm w Afryce. Geneza oraz przebieg konfliktu w Mali w latach 2012-2014, Oświęcim 2016 oraz Państwo Islamskie (ISIS) - Historia powstania, taktyka dziatania, Oświęcim 2019 (red.), a także 
pracy, zatytułowaną Podziat kompetencji w ramach struktury IS oraz ich wptyw na poziom efektywności prowadzonych dziatań, napisał Rafał Zgryziewicz ${ }^{2}$. Następny rozdział, Metody komunikacji ${ }^{3}$, przygotował Jacek Lashmann ${ }^{4}$. Marcin Seńko5 omówił natomiast Dziatalność Państwa Islamskiego we Francji w latach 2014-2016. Ostatni rozdział jest autorstwa Agnieszki Czarnoty-Hooglugt ${ }^{6}$ i nosi tytuł Źródta finansowania Państwa Islamskiego. Oprócz tego praca zawiera bibliografię, ilustracje oraz mapy. Należy przy tym podkreślić brak zakończenia, które spinałoby wszystkie teksty i zawierało jakieś ich podsumowanie oraz analizę wynikających z nich wniosków.

Publikacja nie uwzględnia także uzasadnienia takiego, a nie innego doboru tematów. Dotyczy to najbardziej rozdziału o działalności Państwa Islamskiego na terytorium Francji. Nie ulega wątpliwości, że kraj ten jest jednym z ważniejszych obiektów ataków terrorystycznych, jednak zdaniem recenzenta należałoby raczej opisać ataki wymierzone w USA, gdyż przecież to Stany Zjednoczone stoją na czele koalicji zwalczającej terroryzm muzułmański na świecie.

Publikacja pod redakcją Krzysztofa Danielewicza powstała na podstawie materiałów anglojęzycznych, przejmując nie tylko anglosaski punkt widzenia, ale także nawet częściowo styl i język! Nic zatem dziwnego, że w książce trafiają się makaronizmy, np. „ciekawa wydaje się także oficjalna pozycja Amerykańskiego Departamentu Stanu w odpowiedzi na wnioski

kilkunastu recenzowanych artykułów naukowych. Obecnie właściciel firmy i portalu internetowego - Security in practice"; Krzysztof Danielewicz, https://securityinpractice.eu/ /krzysztof-danielewicz/.

${ }^{2}$ Rafat Zgryziewicz, https://scholar.google.pl/citations?user=XZE8LnsAAAAJ\&h$\mathrm{l}=\mathrm{pl}$.

3 Recenzent chciałby w tym miejscu podziękować magistrowi Tomaszowi Piontkowi za konsultację i wyjaśnienie szeregu kwestii informatycznych.

${ }^{4}$ Niestety na jego temat nie udało się odnaleźć żadnych informacji.

5 Również w tym przypadku przybliżenie informacji o tym autorze okazało się niemożliwe.

${ }^{6}$ Autorka wydaje się mieć więcej do czynienia z biznesem niż bezpieczeńtwem czy historią najnowszą, co w pełni wyjaśnia podjętą przez nią problematykę (zob. "MELIA” AGNIESZKA CZARNOTA-HOOGLUGT \& DIDERIK HOOGLUGT | Rejestr.io, https://rejestr.io/krs/583814/melia-agnieszka-czarnota-hooglugt-diderik-hooglugt, (dostęp: 16.09.2020). 
sunnitów o interwencje” (s. 43). Kolejnym przykładem jest informacja, jakoby Um Sayel miała wychowywać dzieci, „dysponując małą pensją” (s. 10), tymczasem w oryginalnym źródle ${ }^{7}$ znajduje się zwrot a small pension, co oznacza „małą rentę/emeryturę”. Jak widać, nawet tłumaczenie $\mathrm{z}$ angielskiego sprawia czasem autorom kłopot!

Zupełne kuriozum stanowi przypis 148 na s. 31, gdzie pojawia się wyraz insurgency zamiast prostego „powstanie” czy „partyzantka”. Ewentualnie można „zabitych członków insurgency” zastąpić „zabitych insurgentów”. Innym ciekawym przykładem jest prowadzenie działań „za pośrednictwem dedykowanych portali” (s. 84) czy korzystanie z samochodów „specjalnie dedykowanych na potrzeby prowadzonych działań” (s. 68). W obu przypadkach czytelnik ma do czynienia z błędnym tłumaczeniem angielskiego dedicated. Widać także wyraźnie odtwórczy charakter recenzowanej książki.

Następną konsekwencją korzystania z anglojęzycznych materiałów i dowodem ich bezrefleksyjnego kopiowania jest podawanie angielskiego odpowiednika w nawiasie po nazwie polskiej. Przecież nie jest to język oryginału! Czasem też tworzone są kalki będące mieszanką arabskiej transkrypcji i nazwy angielskiej. Co ciekawe, Danielewicz najwyraźniej sądzi, że muzułmańskie obiekty religijne są nazywane w tym języku! Wspomina bowiem takie miejsca, jak „Al-Husayn Ben Ali Mosque w Ammanie” (s. 7). Wprawdzie pisze o „Wielkim Meczecie w Mosulu”, jednak już na s. 16 informuje czytelnika o "Great Mosque of al-Nuri w Mosulu”! Sytuacje takie można byłoby mnożyć, ale ograniczę się do ostatniego już przykładu. Chodzi przy tym o jedno z najbardziej znanych muzułmańskich miejsc kultu, które zostało nazwane „The Aqsa Mosque w Jerozolimie” (s. 29). Czyżby Krzysztof Danielewicz nie znał polskiej nazwy Meczet Al-Aksa?!

Podobne podejście prezentuje w swoim tekście Rafał Zgryziewicz. Wymieniając nazwy poszczególnych departamentów Państwa Islamskiego, w większości przykładów w nawiasie podaje ich anglojęzyczne nazwy np. „Departament Edukacji” (The Diwan of Education) (s. 63). Zdarzają się jednak dziwne hybrydy w rodzaju „Departamentu ds. Dotacji, Modlitw i Meczetów" (The Diwan of Da'wah And Masajid). W tym przypadku

7 Abu Musab al-Zarqawi: a biographical sketch, https://jamestown.org/program/abu-musab-al-zarqawi-a-biographical-sketch/ (dostęp: 29.08.2020). 
pominięto arabskie rodzajniki określone $a l$, a dodano angielskie the, of oraz and. Samo przeliczenie słów uświadamia, że polska nazwa ma trzy elementy (dotacje, modlitwy i meczety), a „oryginalna” jedynie dwa (modlitwy i meczety). Brak kompatybilności występuje również w kwestii tłumaczenia. Da’wah (dảwa) oznacza nie modlitwę (șalāt) ${ }^{8}$, ale działalność misjonarską, zapraszanie do przyjęcia islamu?

W tym kontekście szczególnie kuriozalnie wyglądają transkrypcje arabskie poprzedzone anglosaskim zaimkiem określonym the, jak choćby „The Hisb Al-Tahrir Al-Islam” (Islamic Freedom Party) (s. 12), czyli tak naprawdę Islamska Partia Wyzwolenia (حزب التحرير الإسلامي) (10.

Problem ten dotyczy także postaci historycznych. Danielewicz zdaje się nie wiedzieć, że zamiast pisać o „dynastii Abbasid” (s. 30), należałoby zastosować polską wersję i pisać o „dynastii Abbasydów”. Podobnie wymienia „króla francuskiego Luisa VII [sic!]”, kalecząc przy tym oryginalny zapis imienia (Louis) monarchy, znanego w Polsce jako Ludwik VII. Czyżby nie wiedział, że te nazwy własne mają swoje odpowiedniki w języku polskim i nie należy bezrefleksyjnie kopiować ich z prac anglojęzycznych?

Porażające jest to, że autorzy mieniący się znawcami problematyki ISIS nie tylko nie znają najwyraźniej podstaw języka arabskiego, ale nawet nie potrafią korzystać z dostępnych darmowych narzędzi do tłumaczenia! Nigdzie w książce nie ma informacji na temat tego, czy zastosowano transkrypcję, czy transliterację z języka arabskiego. Brak też jakiejkolwiek refleksji nad zapisem nazw własnych w języku arabskim ${ }^{11}$. Autorzy również, zapewne zależnie od źródła swoich informacji, dowolnie zapisują rodzajnik określony al z literami słonecznymi, raz dokonując jego asymilacji, a raz nie. W efekcie czytelnik zderza się z prawdziwym chaosem, który w praktyce uniemożliwia prawidłowe odczytanie nazwisk postaci czy miejsc.

8 J. Danecki, Podstawowe wiadomości o Islamie, t. 2, Warszawa 2002, s. 308.

9 Ibidem, t. 1, s. 353.

10 Hizb altahrir al'islami, https:/www.aljazeera.net/encyclopedia/movementsandparties/2014/2/12/حزب_التحرير -الإسلامي (dostęp: 21.10.2020).

11 Tymczasem takie zasady są powszechnie dostępne w sieci Internet: http://ksng.gugik.gov.pl/pliki/latynizacja/arabski.pdf. 
Rzekomo Saddam miał umieścić na swej fladze napis: „Bóg jest Wieki, Allahu Akbar” (s. 21). Raczej nie znalazła się tam pierwsza, polskojęzyczna, część. Jeżeli chodzi o drugą, to język arabski ma wspólną formę dla stopnia wyższego i najwyższego. Jeżeli zdanie czy fraza zawiera porównanie, to należy użyć tego pierwszego, w przeciwnym zaś wypadku tego ostatniego. Poprawne tłumaczenie słynnego zwrotu Allahu akbar brzmi zatem: „Allah jest największy”.

Najjaskrawszym przykładem problemów z językiem arabskim, który jest niestety kompromitacją Danielewicza, a jest napis na murze, który miał brzmieć: „Teraz Twoja kolej, Dyktatorze” (It's your turn, Dictator) (s. 51). Nie wiem, po co angielskie tłumaczenie, przydałby się arabski oryginał lub chociaż jego transkrypcja czy transliteracja. Na szczęście na kolejnej stronie znajduje się fotografia wraz z powtórzonym rzekomym polskim tłumaczeniem. Tymczasem w języku arabskim jest napisane (w transkrypcji) irhal ja Baszar (أرحل يا بشار), czyli mniej więcej: „Idź precz Baszar!”" . Niestety nie świadczy to za dobrze o wiarygodności Danielewicza.

$\mathrm{Na}$ s. 63 Zgryziewicz opublikował fotografię przedstawiającą „bilbord umieszczony przy wejściu do Departamentu Skarg i Sądownictwa w prowincji Ar-Rakka". Napis jest oczywiście po arabsku i po jego odczytaniu (oprócz logo Państwa Islamskiego) napisane jest na nim „Rząd Islamski” (ألحكمة الإسلامية) oraz mniejszymi literami „Państwo Islamskie. Wydział Skarg i Sądownictwa. Prowincja Ar-Raqa. Region At-Tabka" (الدولة الإسلامية ديوان القضاء و المظالم ولاية الرقة ظ قطاع الطبقة). Jest to zatem zwykła urzędowa tablica informacyjna, dowodząca trwałości struktur Państwa Islamskiego, a nie jakiś bliżej nieokreślony „bilbord”.

W trakcie lektury książki można odnieść również wrażenie, że jej autorzy nie do końca znają podstawowe zasady islamu, co jest przecież kluczowe dla zrozumienia fenomenu ISIS. Przykładowo Marcin Seńko stwierdza, że we Francji jest „30 tys. osadzonych wyznawców islamu”, ale „wśród osadzonych francuskich islamistów ok. 18 tys. przestrzega ściśle zasad postu w okresie ramadanu” (s. 129). Tymczasem jest to jeden z pięciu filarów

12 Recenzent chciałby w tym miejscu podziękować Muhammadowi, partnerowi językowemu z aplikacji Hello Talk, za odczytanie pierwszego wyrazu oraz przetłumaczenie całego zwrotu. 
islamu, które obowiązują każdego wierzącego w Allaha ${ }^{13}$, a jego niezachowywanie de facto eliminuje z grona muzułmanów. Oczywiście taka osoba nadal jest podatna na indoktrynację czy namowę na powrót do korzeni islamu, a co za tym idzie, radykalizację.

W pracy znalazła się opinia Andrzeja Szymańskiego, że „można równoprawnie stwierdzić, że islam jest, ale i nie jest religią pokoju” (s. 92). W Koranie znajduje się wprawdzie sporo wersetów brzmiących tolerancyjnie, ale należy pamiętać, że księga ta zawiera doktrynę abrogacji: „Kiedy znosimy jakiś znak albo skazujemy go na zapomnienie, przynosimy lepszy od niego lub jemu podobny. Czyż ty nie wiesz, że Bóg jest nad każdą rzeczą wszechwładny?!” 14; „A kiedy My zmieniamy jeden znak na inny - a Bóg wie najlepiej, co zsyła - to oni mówią: »Ty jesteś tylko oszustem! «ecz większość z nich nie wie"15. W ten sposób późniejsze objawienia znoszą sprzeczne z nimi objawienia wcześniejsze. Tolerancyjne fragmenty Koranu powstały w czasie, gdy wspólnota muzułmańska była jeszcze słaba. Wraz ze wzrostem jej siły narracja zmieniła się na bardziej agresywną i ta jest obowiązująca. Dlatego w Koranie znajduje się wiele wezwań do walki w imię religii ${ }^{16}$, a dżihad „oznacza zobowiązanie muzułmanów do walki na rzecz islamu ze wszystkich sił: ziemskimi dobrami i własną osobą, również w aspekcie walki militarnej. Mahomet uważał, iż święta wojna wymaga mobilizacji ze strony wszystkich muzułmanów" ${ }^{17}$. Dla islamu istotne są również hadisy, które w kwestii dżihadu idą znacznie dalej. Przykładowo Mahomet zapytany, co jest najlepsze, miał odpowiedzieć: „wierzyć w Allaha i jego posłańca”, na drugim miejscu wskazał już „uczestnictwo w dżihadzie w sprawie Allaha”,

13 J. Danecki, op. cit., s. 129, 141-143.

14 Surah Al-Baqarah - 2:106, https://quran.com/2/106?translations=18\%2C95 (dostęp: 21.10.2020).

15 Surah An-Nabl - 16:101, https:/quran.com/16/101?translations=18\%2C95 (dostęp: 21.10.2020).

16 K. Kościelniak, Dżihad. Święta wojna w islamie. Związek religii z państwem, islam a demokracja, chrześsijanie w krajach muzutmańskich, Kraków 2006, s. 26-31; idem, Tematyczna konkordancja do Koranu, Kraków 2006, s. 366-368.

17 K. Kościelniak, Dżihad..., s. 31. 
a na trzecim dopiero pielgrzymkę do Mekki ${ }^{18}$. Kiedy indziej zaś miał powiedzieć, że otrzymał rozkaz, „by zwalczać ludzi dopóki nie wyznają, że nie ma boga prócz Allaha i że ja jestem posłańcem Allaha i ustanowią regularne modlitwy i będą płacić jałmużnę"19. Sprawa dżihadu jest znacznie bardziej skomplikowana, jednak muzułmanie traktują go jako obowiązkowy, choć nie przez wszystkich jest on utożsamiany z walką zbrojną.

Dodatkowo prawie każdy rozdział książki wprowadza własne, niestety często płytkie, definicje tych samych kwestii związanych z religią muzułmańską. I tak hadisy są wyjaśnione przez Danielewicza w przypisie 231 na s. 45. Niestety widać przy tym daleko posuniętą inspirację anglojęzyczną Wikipedią. Kolejną ich definicję przywołała Agniesza Czarnota-Hooglugt (s. 144, przypis 49), przy czym podany przez nią odnośnik ${ }^{20}$ nie prowadzi do żadnej definicji hadisów, a jedynie stanowi tłumaczenie kilku z nich, poświęconych dżihadowi. Tymczasem temat ten ma swoją polską literaturę i to do niej należało skierować zainteresowanych ${ }^{21}$.

W książce znajduje się także wiele innych potknięć. Przykładowo Danielewicz pisał, że według „danych 60\% wszystkich mieszkańców liczącej 5,9 mln ludzi Jordanii stanowią Palestyńczycy, którzy przybyli w latach 50. XX wieku do powstającego wówczas państwa Izrael [wyróżnienie J. C.]" (s. 9). Trudno odgadnąć, co autor miał na myśli. Jak wiadomo, deklaracja niepodległości Izraela została ogłoszona 14 maja 1948 r. W toku wojny, która wówczas wybuchła, wielu Arabów palestyńskich bądź zostało wygnanych, bądź uciekło z Palestyny dobrowolnie ${ }^{22}$. W latach 50. zaś

18 Șaḥih al-Bukhārī. The translation of the meanings of Sahih al-Bukhari, Riyadh 1997, vol. 1, s. 67 (ksiega II, rozdział 18).

19 Hadith - The Book of the Sunnah - Sunan Ibn Majah - Sunnah.com - sayings and teachings of prophet muhammad (صلى الله علبه و سلم), https://sunnah.com/urn/1250720 (dostęp: 21.10.2020).

20 SUNAN ABU-DAWUD, BOOK 14: Jihad (Kitab Al-Jihad), https://www.thereligionofpeace.com/quran/dawud/014-sat.htm (dostęp: 16.09.2020).

21 K. Kościelniak, Sunna, hadisy i tradycjoniści: wstęp do tradycji muzutmańskiej, Kraków 2006.

22 K. Kubiak, Wojna o niepodlegtość Izraela 1947-1949, Zabrze 2013. 
dochodziło do prób infiltracji granic i prowadzonych przez Izrael operacji odwetowych $^{23}$.

Wywody Danielewicza na temat miasta Zarqa są tłumaczeniem podanego w przypisie artykułu o Zarqawim, jak choćby cytowany powyżej fragment („More than 60 percent of Jordan's 5.9 million inhabitants are Palestinian, as are some 80 percent of the inhabitants of old Zarqa") ${ }^{24}$. Niemniej jednak dopisek o rzekomo powstającym Izraelu jest najwyraźniej autorski, gdyż w przywołanym tekście go nie ma.

Również od strony stylistycznej książka prezentuje się nie najlepiej. Występuje w niej mnóstwo powtórzeń, które niejednokrotnie brzmią wprost humorystycznie, jak choćby: „emanacją działań psychologicznych są rozpowszechniane produkty oddziaływania psychologicznego" (s. 85). Za inny przykład może posłużyć zdanie: „Państwo Islamskie doskonale nauczyło się wykorzystywać internet do swoich celów i prowadzi wojnę w sieci, wykorzystując do tego urządzenia mobilne oraz media społecznościowe” (s. 102). Podobnie nieporadne jest sformułowanie: „Użytkownik przed użyciem musi wprowadzić kod PIN" (s. 111). Widać tu niestety brak redakcji językowej, która powinna wyeliminować tego typu uchybienia.

\section{Podsumowanie}

Niestety książka Państwo Islamskie (ISIS). Historia powstania i taktyka dziatania to publikacja słaba. Nie przeszła profesjonalnej korekty językowej, toteż jest napisana ciężkim stylem z mnóstwem powtórzeń i anglicyzmów, a także bez jakiejkolwiek próby ujednolicenia arabskich nazw własnych.

23 Do akcji odwetowych powołano nawet specjalną Jednostkę 101 (U. Milstein, Ha-historia szel canchanim. Mi-milchemet ha-acmaut ad milchemet Lebanon, T. 1, Tel Awiw 1985. O konfliktach granicznych Izraela z państwami arabskimi w tym okresie szerzej zob. B. Morris, Israel's border wars, 1949-1956: Arab infiltration, Israeli retaliation, and the countdown to the Suez War, New York-Oxford, England 1993.

24 M. A. Weaver, The short, violent life of Abu Musab al-Zarqawi, 1.07.2006, https:// www.theatlantic.com/magazine/archive/2006/07/the-short-violent-life-of-abu-musab-alzarqawi/304983/ (dostęp: 13.01.2021). 
Można nawet zaryzykować twierdzenie, że jej autorzy w ogóle nie dostrzegli takiej potrzeby! Nie ma bowiem o tym ani słowa we wstępie.

Książka powstała na podstawie materiałów anglojęzycznych, które nie zawsze były nawet właściwie przetłumaczone! Zastanawia przy tym, że wśród osób przedstawianych czytelnikowi jako eksperci od Państwa Islamskiego zabrakło kogoś posługującego się językiem arabskim czy chociażby potrafiącego wytłumaczyć podstawowe kwestie związane z islamem! Z tego względu recenzowana publikacja nie tylko nie stanowi postępu w badaniach nad fenomenem Państwa Islamskiego, lecz także jest jedynie krzywym zwierciadłem, przekazującym w zniekształcony sposób to, co się ukazało (najczęściej w internecie) w języku angielskim. Nie ma to przecież zbyt wiele wspólnego z działalnością naukową. Wydaje się, że ambicje polskich badaczy powinny sięgać znacznie dalej.

Błędy historyczne, które znajdują się w książce, wyraźnie dowodzą natomiast braku znajomości tła opisywanych wydarzeń. Tymczasem bez tego trudno jest zrozumieć współczesność.

Na zakończenie pozostaje wyrazić nadzieję, że autorzy książki Państwo Islamskie (ISIS). Historia powstania i taktyka dziatania, chcąc dalej zajmować się kwestią działalności militarnej muzułmańskich grup zbrojnych czy organizacji terrorystycznych, wyciągną niezbędne wnioski i nadrobią swoje braki przed kolejną publikacją. 